\title{
Biotechnologies and bioinspired materials for the construction industry: an overview
}

\author{
F. Pacheco-Torgal ${ }^{\mathrm{a} *}$ and J.A. Labrincha ${ }^{\mathrm{b}}$ \\ ${ }^{a}$ C-TAC Research Centre, University of Minho, Guimarães, Portugal; ${ }^{b}$ CICECO, University of Aveiro, Aveiro, Portugal
}

(Received 12 February 2013; accepted 19 August 2013)

\begin{abstract}
Looking back to less than three centuries of industrialization, responsible for alarming levels of pollution and consumption of non-renewable resources that has led to the exhaustion of the earth's capacity, the humankind only now begins to grasp the overwhelming potential of natural systems. During almost 40 million centuries, Nature has developed materials and processes with optimal performance which are totally biodegradable. Analysis of bioinspired materials requires the knowledge of both biological and engineering principles which are being a part of a large research area termed biotechnology. This hot area is one of the six strategic Key Enabling Technologies that will be funded under the EU Framework Programme Horizon 2020. This paper reviews the current knowledge on the potential of this emerging field, particularly in the development of materials and technologies for the construction industry. It covers the use of bacteria for enhancing concrete durability and for soil stabilization. It also covers bioinspired tough composite materials, bioinspired adhesives and coatings, and self-cleaning materials. Incorporation of biology basics in the civil engineering curriculum would ease the communication between biologists and civil engineers, helping to foster research on biotechnologies and bioinspired materials for the construction industry.
\end{abstract}

Keywords: biotechconcrete; soil stabilization; bioinspired tough composite materials; bioinspired adhesives and coatings; self-cleaning materials

\section{Introduction}

The development of mechanized systems and the subsequent industrialization process (which occurred in less than three centuries) has created in the humankind the feeling that men have risen above Nature. Unfortunately, the evidence of the opposite came swiftly, accompanied with an unbearable price to be paid. Unlike other species, that seek a balance with Nature which will ensure their survival, the humankind concerns only about the immediate satisfaction of their 'needs', oblivious to the fact that this may cause the exhaustion and the collapse of the ecosystem of which they are an integral part. All of this activity is still continuing despite the constant alert from the scientific community to the urgency of this problem. In the 1970s, Meadows et al. (1972) used a computer model based on the fixed-stock paradigm, to study the interactions between population, food production, industrial production, pollution and the consumption of nonrenewable resources. As a result, they predicted that during the twenty-first century, the earth's capacity would be exhausted, resulting in the collapse of human civilization as we know it. Two decades later, an update of this study was published (Meadows, Randers, and Meadows 1992), showing that some limits had already been crossed. Also, the economics of environmental problems such as the probable meltdown of the world economy associated with global warming has to be taken into account. If we act now, the cost of all the services and products to combat climate change will be $1 \%$ of the gross domestic product (GDP); otherwise, an economic depression of about $20 \%$ of the GDP may take place (Stern 2006). Not least is the fact that human civilization easily forgets the value of services provided free of charge by Nature that reaches almost $33 \times 10^{12}$ dollars per year (Costanza et al. 1998). As a comparison, the global GDP in the world amounted to $18 \times 10^{12}$ dollars per year, which is roughly half the value of services and products provided by Nature.

During the last century, material use has increased 8 -fold and, as a result, the humankind currently uses almost $60\left(10^{15}\right) \mathrm{kg}$ of materials per year (Krausmann et al. 2009). The most important environmental threat associated with its production is not only the depletion of nonrenewable raw materials (Allwood et al. 2011), but also the environmental impacts caused by its extraction, namely extensive deforestation and top-soil loss. Since material demand will double in the next 40 years (Krausmann et al. 2009), this means that its environmental impact will also increase drastically. The global construction industry uses $3 \times 10^{12} \mathrm{~kg}$ of raw material per year (almost $50 \%$ by weight of the total raw material consumption), which is more than that consumed in any other economic activity. This estimate emphasizes the unsustainability of the construction industry. Moreover, since 1930, more than 100,000 new chemical compounds have been developed, and insufficient information exists

*Corresponding author. Email: torgal@ civil.uminho.pt

(C) 2013 Taylor \& Francis 
concerning the health assessment of $95 \%$ of the chemicals (of which a relevant part is used in construction; PachecoTorgal, Jalali, and Fucic 2012). It is expected that in the forthcoming years, the construction industry will keep on growing at a fast pace. The foreseeable increase in the world population (which by 2030 is expected to increase by more than 2 billion people) and their building and infrastructural needs would further increase the consumption of non-renewable materials as well as waste production. Therefore, the use of more sustainable construction materials and construction techniques represents a major contribution to the eco-efficiency of the construction industry and thus to a more sustainable development (Pacheco-Torgal and Jalali 2011). An innovative approach to solve this (and other current technological problems faced by the human society) encompasses a holistic way of perceiving the potential of natural systems (Martin et al. 2010). The continuous improvement of these systems, carried out over 40 million centuries, has led to materials and 'technologies' with exceptional performance that are fully biodegradable, and must now be studied by biologists and engineers (Benyus 1997; Gebeshuber, Gruber, and Drack 2009). The Biomimicry Institute, for example, since November 2008, has been providing the AskNature online library of research articles on biomimetic design indexed by function. The term biomimetics was used first time by Otto Schmitt during the 1950 s and relates to the development of novel technologies through the distillation of principles from the study of biological systems (Lepora, Verschure, and Prescott 2013). Other terms such as 'biomimicry', 'bioinspiration', and 'bioinspired' are derived words from 'biomimetic', and 'bioinspired' is sometimes used to connote a presumed heir of the word biomimetic (Shimomura 2010). Other authors (Chen, McKittrick, and Meyers 2012) have reported that the study of biological systems as structures dates back to the early parts of the twentieth century with the work of D'Arcy W. Thompson, first published in 1917. Analysis of bioinspired materials requires the knowledge of both biological and engineering principles which are being a part of a large research area termed biotechnology. Biotechnology is one of the world's fastest growing industries, being one of the six Key Enabling Technologies (KETs 2009; Pacheco-Torgal 2013) that will be funded under the EU Framework Programme Horizon 2020. Although biologically inspired design is inherently interdisciplinary requiring expertise across two disparate domains (engineering and biology), biologists and engineers, in fact, typically speak a very different language, creating communication challenges (Helms, Vattam, and Goel 2009). Therefore, changes in the civil engineering curriculum are also needed.

\section{Biotechconcrete}

Biomineralization is defined as a biologically induced precipitation of crystals by which micro-organisms create a local micro-environment, with conditions that allow for an optimal extracellular chemical precipitation of mineral phases such as calcium carbonate $\left(\mathrm{CaCO}_{3}\right)$ (Hamilton 2003). The decomposition of urea by ureolytic bacteria is one of the most common pathways to precipitate $\mathrm{CaCO}_{3}$. The microbial urease enzyme catalyses the hydrolysis of urea into ammonium and carbonate. Ammonia released into the surroundings subsequently increases the $\mathrm{pH}$, leading to the accumulation of insoluble $\mathrm{CaCO}_{3}$ in a calcium-rich environment. Figure 1 shows a simplified representation of the events occurring during the ureolyticinduced carbonate precipitation. Ramachandran, Ramakrishnan, and Bang (2001) reported that the use of Sporosarcina pasteurii has a positive influence on the
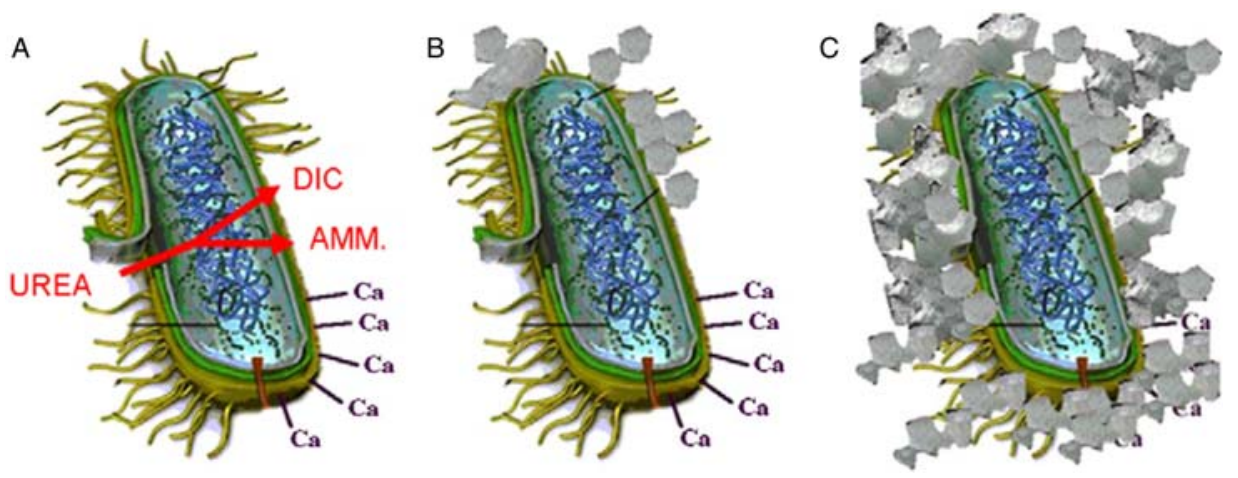

Figure 1. Simplified representation of the events occurring during ureolytic-induced carbonate precipitation. Calcium ions in the solution are attracted to the bacterial cell wall due to the negative charge of the latter. Upon addition of urea to the bacteria, dissolved inorganic carbon (DIC) and ammonium (AMM) are released into the microenvironment of the bacteria (A). In the presence of calcium ions, this can lead to local supersaturation and hence heterogeneous precipitation of calcium carbonate on the bacterial cell wall (B). After a while, the whole cell becomes encapsulated (C). (C) [Elsevier]. Reproduced by permission of De Muynck, De Belie, and Verstraete (2010). Permission to reuse must be obtained from Elsevier. 
performance of cementitious composites. Ghosh et al. (2009) reported that anaerobic hot-spring bacteria leach silica and help in the formation of new silicate phases that fill the micro-pores. They also reported that a concentration of $10^{5}$ cells $/ \mathrm{ml}$ optimizes the microstructure of cementitious composites. To overcome the problem of excessive ammonia production associated with the use of the genus Bacillus, Jonkers et al. (2010) used bacterial spores (Bacillus cohnii). They reported a loss of bacteria that is linked to the continuing decrease in the pore size of the matrix with the progress of concrete curing. To avoid bacterial loss, the authors suggested the encapsulation of bacteria prior to the addition to the concrete mixture or else, the addition of air-entraining agents. Reddy et al. (2010) reported that the use of Bacillus subtilis with a cell concentration of $10^{5}$ cells $/ \mathrm{ml}$ of water increases the resistance of concrete to sulphuric acid attack. For the same bacteria, an optimum concentration of $10^{6}$ cells $/ \mathrm{ml}$ has been reported by other authors (Afifudin et al. 2011). Van Tittelboom et al. (2010) confirmed that the use of bacteria can help to reduce the water permeability of concrete; however, they reported that the highly alkaline $\mathrm{pH}$ of concrete hinders the growth of bacteria. To overcome this problem, they immobilized the bacteria in silica gel. Other authors have already suggested the use of polyurethane foam to immobilize the bacteria (Bang, Galinat, and Ramakrishnan 2001). According to Achal, Pan, and Ozyurt (2011), fly ash concrete containing the cells of Bacillus megaterium absorbed nearly 3.5 times less water than the control concrete. They have also found that the permeability of the concrete with bacterial cells was lower than that of the control concrete. Wiktor and Jonkers (2011) reported that the combined effect of viable bacterial spores plus calcium lactate embedded in porous clay particles significantly enhanced mineral precipitation at crack surfaces, further resulting in the healing of cracks with a maximal width of $0.46 \mathrm{~mm}$. They have also reported that since bacteria consume oxygen, it may provide an additional benefit associated with the potential to inhibit reinforcement corrosion. Chahal, Siddique, and Rajor (2012) studied the influence of $S$. pasteuri on fly ash concrete, revealing that the optimum performance is achieved at a concentration of $10^{5}$ cells $/ \mathrm{ml}$ bacteria. These authors have reported a four-time reduction in water absorption and an eight-time reduction in chloride permeability due to calcite deposition. Wang, De Belie, and Verstraete (2012) suggested the use of diatomaceous earth to protect the bacteria Bacillus sphaericus from the high $\mathrm{pH}$ of the concrete matrix. These authors have reported that bacteria immobilized in diatomaceous earth has much higher ureolytic activity $(12-17 \mathrm{~g} / \mathrm{l}$ urea was decomposed within 3 days) than unimmobilized bacteria $(<1 \mathrm{~g} / 1$ urea was decomposed within the same time span) in the cement slurry. The optimal concentration of diatomaceous earth for immobilization was $60 \%$ (in w/v ratio, weight of diatomaceous earth/volume of bacterial suspension). Wang et al. (2012) compared the performance of two different techniques (silica gel and polyurethane) to protect the bacteria when immobilized inside the concrete. The silica gel technique uses Levasil ${ }^{\circledR} 200 / 30 \%$ with a specific surface area of $200 \mathrm{~m}^{2} / \mathrm{g}$. Also, a solid content of $30 \%$ was used to embed the bacterial cells. To immobilize the bacteria into polyurethane, a two-component polyurethane, MEYCO MP $3551 \mathrm{~K}$ (BASF), was used. The incorporation of the bacteria into mortar specimens was achieved through glass tubes with a length of $40 \mathrm{~mm}$ and an inner diameter of $3 \mathrm{~mm}$. Experimental results showed that silica gel-immobilized bacteria exhibited a higher activity than polyurethane-immobilized bacteria, and hence more $\mathrm{CaCO}_{3}$ was precipitated in silica gel $(25 \%$ by mass) compared with polyurethane (11\% by mass). These values were validated by thermogravimetric analysis. However, cracked mortars specimens treated with polyurethane-immobilized bacteria had a lower water permeability coefficient $\left(10^{-10}\right.$ to $\left.10^{-11} \mathrm{~m} / \mathrm{s}\right)$ compared with specimens treated with silica gel-immobilized bacteria, which showed a water permeability coefficient of $10^{-7}$ to $10^{-9} \mathrm{~m} / \mathrm{s}$. In summary, the use of bacteria in concrete induces mineral precipitation that helps fill micro-pores and cracks, thus reducing its permeability. However, as the highly alkaline $\mathrm{pH}$ of concrete hinders the growth of bacteria, different authors have suggested the use of different immobilization solutions (clay capsules, silica gel or polyurethane encapsulation).

\section{Soil stabilization}

The use of biomineralization for increasing the strength and stiffness of unconsolidated sands and gravels interests the construction industry for geotechnical purposes as well as for rammed earth masonry purposes (Pacheco-Torgal and Jalali 2012). This process allows for the reduction of traditional stabilizing agents (Portland cement and lime), being, in fact, associated with lower $\mathrm{CO}_{2}$ emission levels. It can also be used to replace toxic and/or hazardous chemical grouts that can be responsible for water poisoning (De Jong et al. 2010). The terms biogrouting, biocementing and microbially induced calcite precipitation (MICP) are also used to characterize this process (De Jong et al. 2011). This innovative technique can use different micro-organisms and enzymes and is suitable for a wide range of soil types (Mortensen et al. 2011; Jian et al. 2012). Some authors (González, Carvalho, and Valência 2012) have studied the addition of nutrients to the soil ( $15 \mathrm{~g}$ calcium acetate, $4 \mathrm{~g}$ yeast extract and $5 \mathrm{~g}$ glucose to 1 litre of distilled water, $\mathrm{pH}$ 8.0) to induce biomineralization caused by the native bacteria existing in the soil. Kim et al. (2012) studied the biotreatment of loose sand and soft silt containing different types of bacteria, reporting a significant increase in compressive strength. 


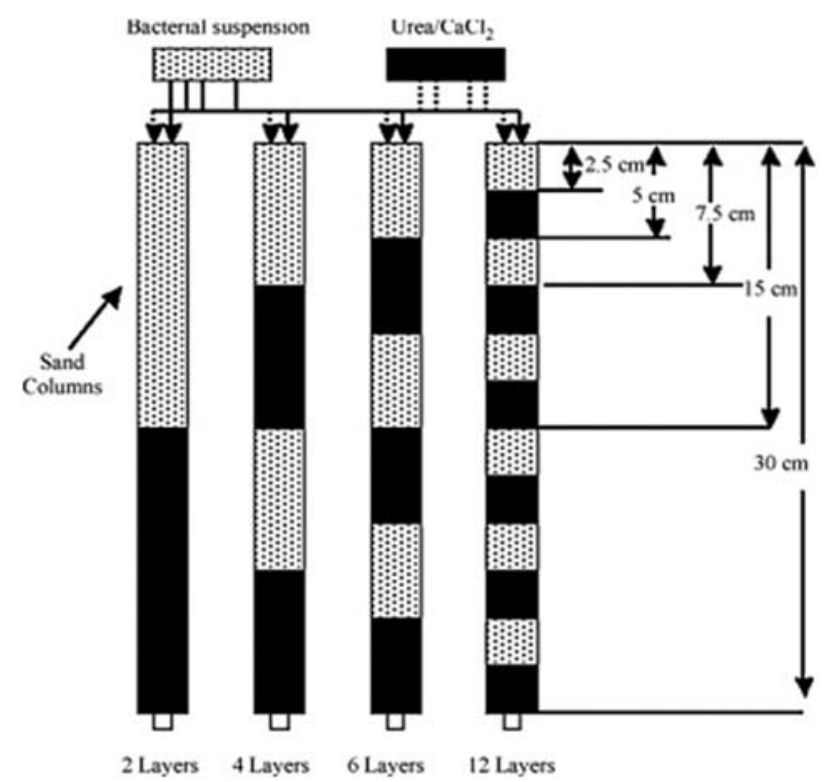

Figure 2. Diagram of bacteria placement by introducing different numbers of alternating layers (bacterial suspension/ $\mathrm{CaCl}_{2}+$ urea). (C) [Elsevier]. Reproduced by permission of Cheng and Cord-Ruwisch (2012). Permission to reuse must be obtained from Elsevier.

Chu, Stabnikov, and Volodymyr (2012) reported the formation of a crust layer with a compressive strength of 35.9 MPa. Recent pilot applications have shown promising results in the stabilization of gravel layers (Van Passen 2011). Van Passen et al. (2010) also reported the results of a large-scale experiment $\left(100 \mathrm{~m}^{3}\right)$ in which a two-phase injection of bacterial suspension and cementation solution was used. Initially, a solution of suspended bacteria was injected into a soil. This was followed by the addition of a fixation solution consisting of $50 \mathrm{mM} \mathrm{CaCl}$. These authors have concluded that the stiffness increase could be quantified as a function of the injected volume of grouting agents and the distance from the injection points. To overcome the problem of the heterogeneous distribution of the bacteria in the soil, Keykha et al. (2012) suggested the use of an electrokinetic technique. Van Wijngaarden et al. (2012) developed a method for the injection of bacteria that addresses three possible phases: bacteria in suspension, adsorbed bacteria and fixed bacteria. Because direct measurement of soil properties is not a practical way to assess biomineralization efficiency, several authors have used seismic velocity and resistivity measurements to assess their ability to monitor the extent and spatial distribution of MICP in sands (Weil et al. 2012). Cheng and Cord-Ruwisch (2012) developed a new MICP variation that works for unsaturated sand. The new technique requires the percolation of alternate solutions containing a solution of $B$. sphaericus or a cementation solution containing calcium ions $\left(1 \mathrm{M} \mathrm{CaCl}_{2}\right.$ and $1 \mathrm{M}$ urea; Figure 2 and Table 1). These authors have reported that this method allows for up to three times higher strengths reached with the same amount of chemicals, thus representing a potentially more cost-effective solution. They have also reported that further investigations are needed to evaluate the suitability of this new method in the case of coarse sands and silty soils.

\section{Bioinspired tough composite materials}

An excellent example of the toughness of natural composites is represented by the spider's silk. This material possesses a strength/mass ratio that exceeds that of steel and a toughness that is higher than that of Kevlar ${ }^{\circledR}$ fibres (Porter and Vollrath 2007). Although it is not foreseeable that (in a short-term) organic composites with similar performance will be used in the construction industry, such astonishing performances has in fact inspired the development of high-performance composite materials. One example is the new ceramic-metal (bulk) composite (Launey et al. 2010) that is inexpensive and lightweight and displays exceptional damage-tolerance properties. Another example of the remarkable mechanical performance of natural composites can be found in abalone nacre shells. These shells are composed of $0.2 \mathrm{~mm}$-thick layers, with each layer comprising a $0.5 \mu \mathrm{m}$ thick 'mortar' of calcium carbonate crystals, bound together by proteins. The final result is a composite material with a toughness of 3000 times the toughness of the calcium carbonate crystals ( $\mathrm{Li}$ et al. 2004; Meyers et al. 2009). Figure 3 shows the strength characteristics of abalone nacre shells with respect to the loading direction. Conch shells have a structure that is quite different from abalone nacre shells, i.e. they possess a spiral configuration (Figure 4(a)). The structure of the conch shell consists of three macrolayers that are themselves organized into first-order lamellae, which in their turn comprise second-order lamellae (Meyers et al. 2008). These are made up of tiles named third-order lamellae in

Table 1. Urease activity fixation and urea conversion in $1 \mathrm{~m}$ sand columns. (C) [Elsevier]. Reproduced by permission of Cheng and Cord-Ruwisch (2012). Permission to reuse must be obtained from Elsevier.

\begin{tabular}{llcr}
\hline Sand sample & Bacterial placement & Bacteria retention $(\%)$ & Urea conversion $(\%)$ \\
\hline Surface percolation & Two alternating layers & 60 & 77 \\
& Six alternating layers & 85 & 92 \\
\hline
\end{tabular}




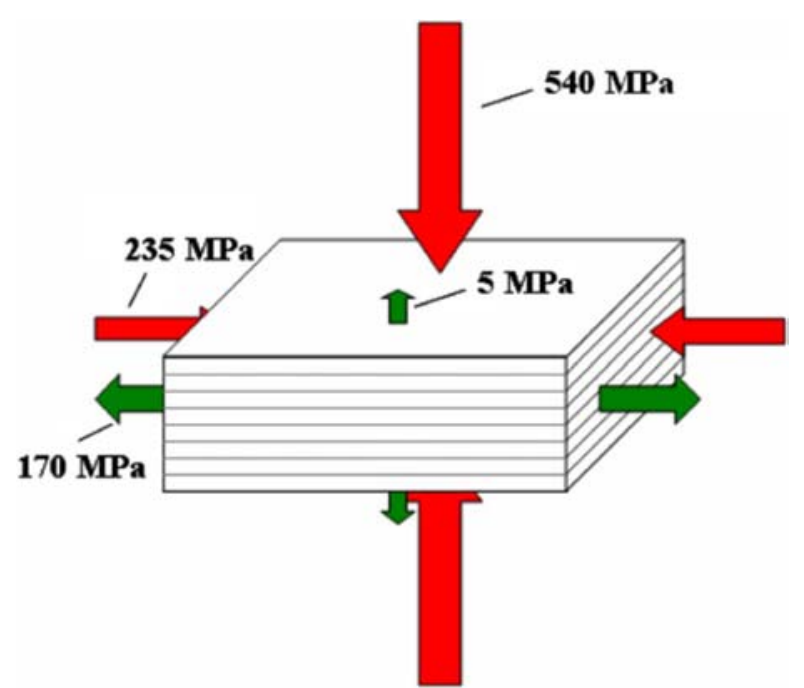

Figure 3. Strength of abalone nacre with respect to the loading direction. (C) [Elsevier]. Reproduced by permission of Meyers et al. (2009). Permission to reuse must be obtained from Elsevier.

such a manner that successive layers are arranged in a tessellated ('tweed') pattern similar to the one used in Brunelleschi's Duomo (Florence, Italy) (Figure 4(c)). Mayer (2006) engaged in the biomimicry study of nacreous composites (Figure 5) at a macroscopic scale, concluding that one of the keys to toughening appears to be a unique ligament formation of the adhesive component. This results in high values of both the resilience and the extensibility of segmented composite beams when subjected to bending. The author has also reported that the beams composed of segmented composites showed significantly higher fracture loads than either monolithic alumina or continuous layered beams.

\section{Bioinspired adhesives and coatings}

Another very useful biomimetic-related finding relates to the development of non-toxic adhesives. The relevance of this subject relates to the fact that the synthetic adhesives currently used by the construction industry are based on epoxy, melamine-urea-formaldehyde, phenol or organic solvents. These compounds are toxic and responsible for the development of eczema, dermatitis and even cancer (Pacheco-Torgal, Jalali, and Fucic 2012). The natural glue produced by mussels and barnacles assures a high adhesion to submerged rocks (Hedlund et al. 2004; Khandeparker and Chandrashekhar 2007; Kamino 2010), equivalent to synthetic adhesives. Recent investigations in the field of bioinspired adhesives have aimed to develop reversible wet/dry adhesives inspired by mussels and geckos. The gecko relies on footpads composed of specialized keratinous foot hairs called setae, which are subdivided into terminal spatulae of approximately $200 \mathrm{~nm}$. These nanostructures generate strong, but temporary, adhesive forces, permitting rapid detachment and reattachment of the gecko foot during locomotion. Since gecko adhesion is greatly diminished upon full immersion in water, Lee, Lee, and Messersmith (2007) developed a hybrid biologically inspired adhesive that mimics gecko foot structures coated with a thin layer of a synthetic polymer that mimics the wet adhesive proteins found in mussels. The results showed that the wet adhesion of this new material increased nearly 15 -fold when coated with mussel-mimetic polymer. The authors have reported that this system maintained its adhesive performance for over a thousand contact cycles in both dry and wet environments. Another mussel bioinspired application relates to the development of coatings for different substrates (Lee et al. 2007). Faure et al. (2012) developed a durable anti-biofilm coating suited for industrial stainlesssteel surfaces. Other authors have reported the development of an efficient and environmentally friendly biocoating for stainless-steel surfaces with enhanced corrosion protection (Yu et al. 2012). This coating was inspired in bioadhesive proteins excreted by the marine mussel Mytilus edulis and based on 3,4-dihydroxyphenylalanine (DOPA).

\section{Self-cleaning materials}

Water-repellent materials are one of the features of natural systems. Lotus leaves are water repellent and have a structure that promotes self-cleaning. The development of scanning electron microscope in the 1960s enabled the study of lotus leaf structure. The epidermal cells of the lotus leaf form papillae that act as microstructure roughness. The papillae are superimposed with a very dense layer of epicuticular waxes (wax crystals), also referred to as hair-like structures (Samaha, Tafreshi, and Gad-el-Hak 2012). Epicuticular waxes themselves have hydrophobic properties, which together with micro- and nanostructure roughnesses result in a reduced contact area between water droplets and the leaf's surface. This combination results in static contact angles (CA) exceeding $150^{\circ}$ on lotus leaves (Samaha, Tafreshi, and Gad-el-Hak 2012). According to definition, wettability is usually determined by measuring the CA of a water droplet on a solid surface. For a solid surface, when the CA of the water on it is $>150^{\circ}$, it is called superhydrophobic. To date, self-cleaning has been demonstrated by the following four conceptual approaches (Liu and Jiang 2012):

(a) $\mathrm{TiO}_{2}$-based superhydrophilic self-cleaning;

(b) lotus effect self-cleaning (superhydrophobicity with a small sliding angle);

(c) gecko setae-inspired self-cleaning and

(d) underwater organism-inspired antifouling selfcleaning.

Considering only the cost of cleaning graffiti (in the city of Los Angeles, this could amount to 100 million euro/ year; Castano and Rodriguez 2003), one can realize the 
(a)

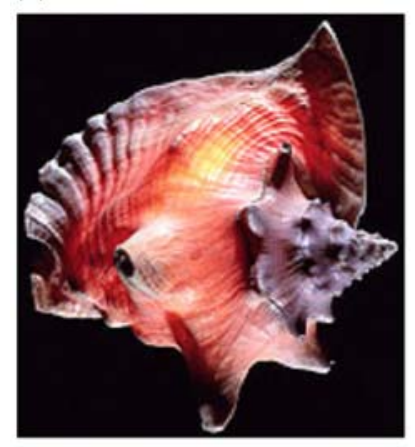

(b)

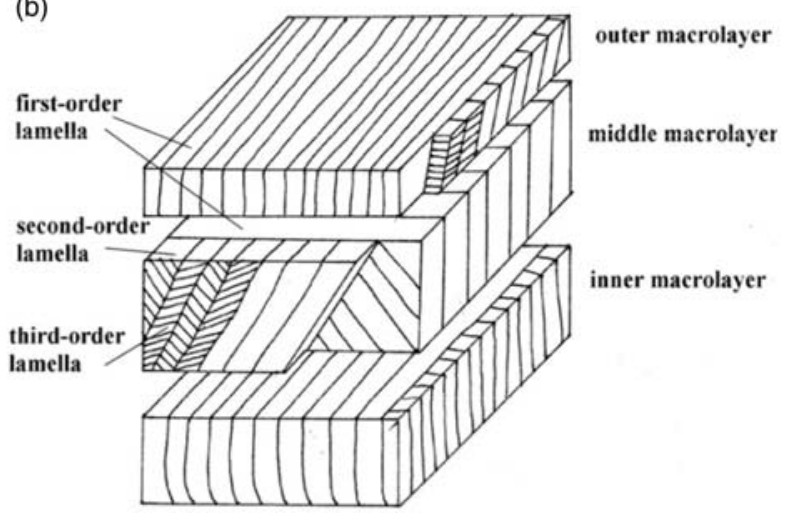

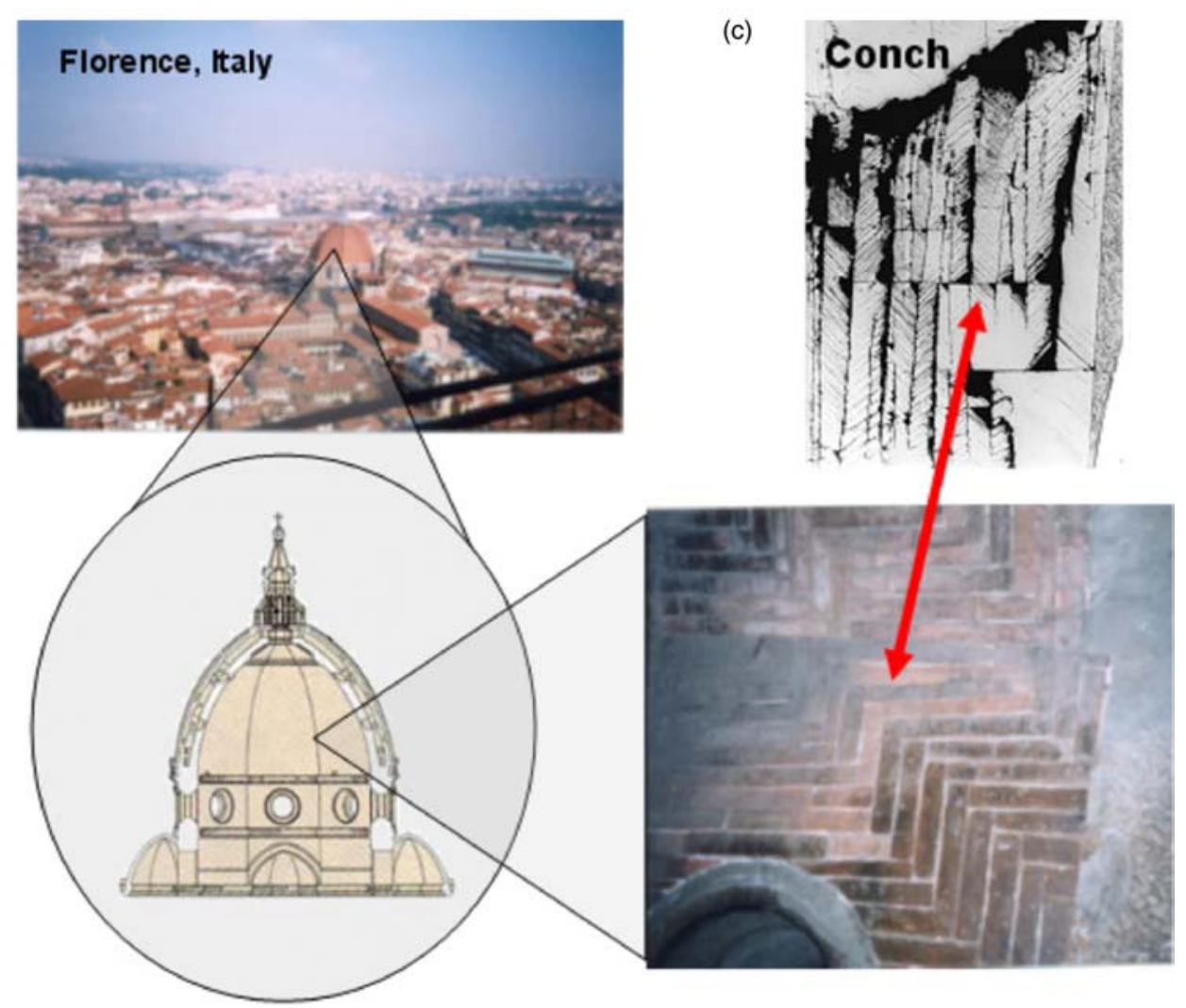

Figure 4. (a) Conch shell: overall view; (b) schematic drawing of the crossed-lamellar structure. Each macroscopic layer is composed of first-, second- and third-order lamellae; (c) tesselated bricks on Brunelleschi's Duomo (Florence, Italy) and equivalent structure of the conch shell. (C) [Elsevier]. Reproduced by permission of Meyers et al. (2008). Permission to reuse must be obtained from Elsevier.

huge economic potential of self-cleaning materials. Since ice storms can result in serious traffic disruption in some main highways and railway lines, this means that antiicing properties also constitute a fundamental property of self-cleaning materials (Guo, Liu, and Su 2011).

\section{Easing the collaboration between civil engineering and biology}

To foster the research on bioinspired materials and biotechnologies for the construction industry, changes in the civil engineering curriculum are expected (De Jong, Mortensen, and Martinez 2007). Cattano, Nikou, and Klotz (2011) recently presented a tested teaching approach on biomimicry to civil engineering students. Other authors have stated that biology knowledge is of particular interest for civil engineers, defending that a more interdisciplinary approach is needed (Knippers and Speck 2012). Teaching biology principles to civil engineers would enhance the collaboration between civil engineering and biology (Pacheco-Torgal et al. 2013a, 2013b). In addition to what was recognized by the high-level expert group on the 


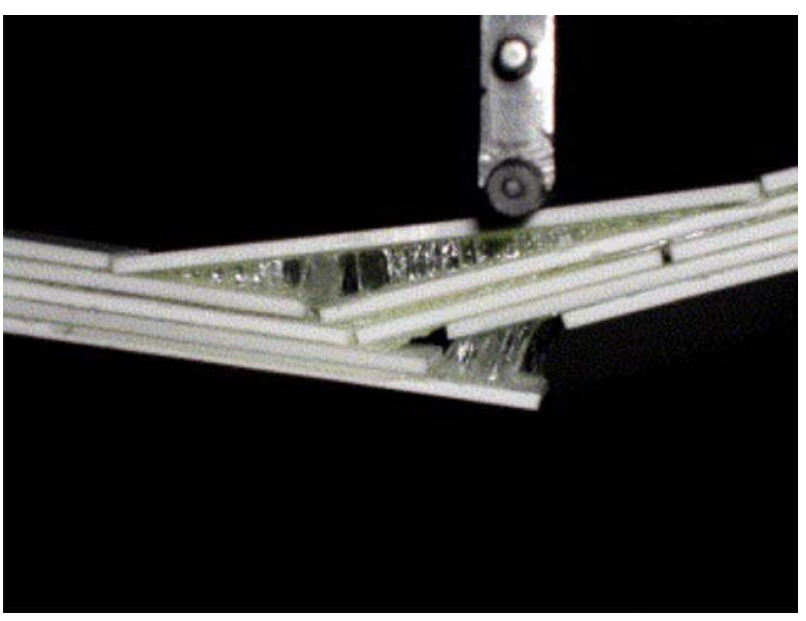

Figure 5. Photograph of a beam being deflected in bending, showing tenacious ligament formation in the thin adhesive phase between the platelets (VHB9473 adhesive). (C) [Elsevier]. Reproduced by permission of Mayer (2006). Permission to reuse must be obtained from Elsevier.

exploitation of KETs, transdisciplinarity requires 'new skills and competencies that current linear training and education cannot supply' (KETs 2009). This can also constitute an opportunity to refresh the civil engineering curriculum in order to tackle its decline in terms of career attractiveness. In this respect, it is important to mention that several authors have reported a severe reduction in undergraduate applications to civil engineering in the UK (Byfield 2001, 2003; Edwards, Dainty, and Love 2004). In Portugal, this reduction has exceeded $60 \%$ in the last 5 years. Lawless (2005) reported that South Africa faces the same problem. India is also facing a severe shortage of civil engineers to tackle its huge infrastructural development targets. A part of the explanation for the low attraction capability of civil engineering in that country relates to the fact that this course is viewed as 'brick and mortar engineering' (Chakraborty 2011). Another reason has to do with the fact that, in some countries (such as the USA), the engineering profession has a negative image. Also, engineers are viewed as dull individuals in contrast 'to the image of a true renaissance engineer, Leonardo da Vinci who was creative and literate... an accomplished painter, architect and scientist' (Yurtseven 2002). The solution for this will require changes in the civil engineering curriculum. These changes must incorporate liaisons to high technology hot areas as well as generate the development of 'soft skills', so that future civil engineers can be more creative, more literate, more socially responsible and with a more entrepreneurial attitude. As Tryggvason and Apelian (2006) wisely put it: 'an entrepreneurial/enterprising engineer who knows everything, can do anything, works with anybody anywhere'. The upgrade of the civil engineering curriculum in the biotech area could help refresh its image. Also, a new name may be in order because, as Singh (2007) put it, "the word "civil" in "civil engineering" is anachronistic and does not represent the works of the so-called civil engineer'. As a consequence, civil engineering is 'the only engineering discipline to have a name that does not represent the works it undertakes'. Nanotechnology could also help to convey a new vision for civil engineering (Zheng et al. 2011). Better yet, the changes in the civil engineering curriculum could be made in the context of a grand cause such as the Seventh Millennium Development Goal (Pacheco-Torgal and Labrincha 2013).

\section{Conclusions}

As a part of being one of the six strategic KETs that will be funded under the EU Framework Programme Horizon 2020, biotechnology could constitute, in the future, a hot area, allowing for radical changes in the construction industry. The use of bacteria in concrete needs further research efforts to identify which calcite-producing bacteria are more efficient in highly alkaline environment or which is the most eco-efficient encapsulation method. The use of biomineralization for increasing the strength and stiffness of unconsolidated sands and gravels allows for the reduction of traditional stabilizing agents (Portland cement and lime), being associated with lower $\mathrm{CO}_{2}$ emission levels. Bioinspired tough composite materials are still in the early stages of development, and there is much to learn from the optimal performance of natural systems. Despite promising investigations related to the development of non-toxic bioadhesives, the construction industry is in fact still based on epoxy, melamine-urea-formaldehyde, phenol or organic solvents. These toxic compounds are responsible for the development of eczema, dermatitis and even cancer. Research on self-cleaning materials has had an exponential growth in the last decade, but still much needs to be investigated. Research in the field of bioinspired construction materials and biotechnologies requires an interdisciplinary collaboration between biologists and civil engineers. The civil engineering curriculum needs to incorporate biology basics in order to ease the communication between biologists and civil engineers. This could constitute an opportunity to refresh the civil engineering curriculum and to tackle the decline in undergraduate course applications.

\section{References}

Achal, V., X. Pan, and N. Ozyurt. 2011. "Improved Strength and Durability of Fly Ash-Amended Concrete by Microbial Calcite Precipitation." Ecological Engineering 37: 554-559.

Afifudin, H., M. Hamidah, H. Hana, and K. Kartini. 2011. "Microorganism Precipitation in Enhancing Concrete Properties." Applied Mechanics and Materials 99-100: 1157. doi:10.4028/www.scientific.net/AMM.99-100.1157 
Allwood, J., M. Ashby, T. Gutowski, and C. Worrell. 2011. "Material Efficiency: A White Paper." Resources, Conservation and Recycling 55: 362-381. doi:10.1016/j. resconrec.2010.11.002.

Bang, S., J. Galinat, and V. Ramakrishnan. 2001. "Calcite Precipitation Induced by Polyurethane-Immobilized Bacillus Pasteurii." Enzyme Microbiology Technology 28: 404-409. doi:10.1016/S0141-0229(00)00348-3.

Benyus, J. M. 1997. Biomimicry: Innovation Inspired by Nature. New York: William Morrow.

Byfield, M. P. 2001. "Graduate Shortage: The Key to Civil Engineering's Future?" Proceedings of the Institution of Civil Engineers: Civil Engineering 144: 161-165. doi:10. 1680/cien.2001.144.4.161.

Byfield, M. P. 2003. "British Civil Engineering Skills: Defusing the Time Bomb." Proceedings of the Institution of Civil Engineers: Civil Engineering 156: 183-186. doi:10.1680/ cien.2003.156.4.183.

Castano, V., and R. Rodriguez. 2003. "A Nanotechnology Approach to High Performance Anti-Graffiti Coatings." Presentation at the Nanotechnology in Crime Prevention Conference, London.

Cattano, C., T. Nikou, and L. Klotz. 2011. "Teaching Systems Thinking and Biomimicry to Civil Engineering Students." Journal of Professional Issues in Engineering Education and Practice 137: 176-182. doi:10.1061/(ASCE)EI.1943-5541. 0000061.

Chahal, N., R. Siddique, and A. Rajor. 2012. "Influence of Bacteria on the Compressive Strength, Water Absorption and Rapid Chloride Permeability of Fly Ash Concrete." Construction and Building Materials 28: 351-356. doi:10. 1016/j.conbuildmat.2011.07.042.

Chakraborty, S. 2011. “Assessment of Civil Engineering Inputs for Infrastructure Development.” New Delhi: Indian National Academy of Engineering. Accessed September 9, 2012. http:// www.inae.org/research_studies_civil_engineering.html

Chen, P.-Y., J. McKittrick, and M. Meyers. 2012. "Biological Materials: Functional Adaptations and Bioinspired Designs." Progress in Materials Science 57: 1492-1704. doi:10.1016/j. pmatsci.2012.03.001.

Cheng, L., and R. Cord-Ruwisch. 2012. "In Situ Soil Cementation with Ureolytic Bacteria by Surface Percolation." Ecological Engineering 42: 64-72. doi:10.1016/j. ecoleng.2012.01.013.

Chu, J., V. Stabnikov, and I. Volodymyr. 2012. "Microbially Induced Calcium Carbonate Precipitation on Surface or in the Bulk of Soil." Geomicrobiology Journal 29: 544-549. doi:10.1080/01490451.2011.592929.

Costanza, R., R. d'Arge, R. de Groot, S. Farber, M. Grasso, B. Hannon, K. Limburg, et al. 1998. "The Value of the World's Ecosystem Services and Natural Capital." Nature 387: 253-260.

De Jong, J. T., B. Mortensen, and B. Martinez. 2007. "Bio-Soils Interdisciplinary Science and Engineering Initiative." NSF Final Report on Workshop. Accessed September 9, 2012. http://www.sil.ucdavis.edu/NSF-EPSRC\%20Bio-Soils\% 20Workshop\%20-\%20NSF\%20Final\%20Report.pdf

De Jong, J. T., B. Mortensen, B. Martinez, and D. Nelson. 2010. "Bio-Mediated Soil Improvement." Ecological Engineering 36: 197-210. doi:10.1016/j.ecoleng.2008.12.029.

De Jong, J. T., K. Soga, S. Banwart, W. Whalley, T. Ginn, D. Nelson, B. Mortensen, B. Martinez, and T. Barkouki. 2011. "Soil Engineering In Vivo: Harnessing Natural Biogeochemical Systems for Sustainable, Multi-Functional Engineering
Solutions." Journal of the Royal Society Interface 8: 1-15. doi:10.1098/rsif.2010.0270.

De Muynck, W., N. De Belie, and W. Verstraete. 2010. "Microbial Carbonate Precipitation in Construction Materials: A Review." Ecological Engineering 36: 118-136. doi:10.1016/j.ecoleng.2009.02.006.

Edwards, D. J., A. Dainty, and P. Love. 2004. "A Sustainable Cohort of Professional Civil Engineering Graduates? Uncovering the United Kingdom Graduate Crisis." International Education Journal 5: 374-384.

Faure, E., C. Vreuls, C. Falentin-Daudré, G. Zocchi, C. Van de Weerdt, J. Martial, C. Jérôme, A. Duwez, C. Detrembleur, and A. Green. 2012. "A Green and Bio-Inspired Process to Afford Durable Anti-Biofilm Properties to Stainless Steel." Biofouling 28: 719-728. doi:10.1080/08927014.2012. 704366.

Gebeshuber, I., P. Gruber, and M. Drack. 2009. "A Gaze into the Crystal Ball: Biomimetics in the Year 2059." Proc. IMechE 223 Part C: Journal of Mechanical Engineering Science 223: 2899-2918.

Ghosh, P., M. Biswas, B. Chattopadhyay, and S. Mandal. 2009. "Microbial Activity on the Microstructure of Bacteria Modified Mortar." Cement and Concrete Composites 31: 93-98. doi:10.1016/j.cemconcomp.2009.01.001.

González, Y., J. Carvalho, and L. Valência. 2012. "A Field Study on the Improvement of a Tropical Soil with Biotechnological Techniques." DYNA (Colombia) 79: 56-65.

Guo, Z., W. Liu, and B. L. Su. 2011. "Superhydrophobic Surfaces: From Natural to Biomimetic to Functional." Journal of Colloid and Interface Science 353: 335-355. doi:10.1016/j.jcis.2010.08.047.

Hamilton, W. A. 2003. "Microbially Influenced Corrosion as a Model System for the Study of Metal-Microbe Interactions: A Unifying Electron Transfer Hypothesis." Biofouling 19: 65-76.

Hedlund, J., M. Berglin, A. Sellborn, M. Andersson, L. Delage, and H. Elwing. 2004. "Marine Adhesives as Candidates for New Biomaterial." In Transactions of the 7th World Biomaterials Congress. Clayton, Victoria, Australia: Australian Society for Biomaterials, Inc.

Helms, M., S. Vattam, and A. Goel. 2009. "Biologically Inspired Design: Process and Products." Design Studies 30: 606-622.

Jian, C., I. Valodymyr, V. Stabnikov, H. Jia, L. Bing, and M. Naemi. 2012. "Biocement: Green Building and Energy Saving Material." Advanced Materials Research 347-353: 4051-4054. doi:10.4028/www.scientific.net/AMR.347353.4051

Jonkers, H., A. Thijssen, G. Muyzer, O. Copuroglu, and E. Schangen. 2010. "Application of Bacteria as Self-Healing Agent for the Development of Sustainable Concrete." Ecological Engineering 36: 230-235. doi:10.1016/j.ecoleng.2008.12.036.

Kamino, K. 2010. "Molecular Design of Barnacle Cement in Comparison with Those of Mussel and Tubeworm." The Journal of Adhesion 86: 96-110. doi:10.1080/ 00218460903418139.

KETs. 2009. High Level Expert Group. Final Report. Brussels: Taylor \& Francis.

Keykha, H., B. Huat, A. Asadi, and S. Kawasaki. 2012. "ElectroBiogrouting and Its Challenges." International Journal of Electrochemical Science 7: 1196-1204.

Khandeparker, L., and A. Chandrashekhar. 2007. "Underwater Adhesion: The Barnacle Way." International Journal of Adhesion and Adhesives 27: 165-172. doi:10.1016/j. ijadhadh.2006.03.004. 
Kim, D., P. Kyung-Ho, K. Si-Wouk, and K. Sungho. 2012. "A Novel Approach to Induce Cementation of Loose Soils." Advanced Science Letters 9: 545-550. doi:10.1166/asl.2012. 2649.

Knippers, J., and T. Speck. 2012. "Design and Construction Principles in Nature and Architecture." Bioinspiration \& Biomimetics 7: 015002.

Krausmann, F., S. Gingrich, N. Eisenmenger, H. Haberl, and M. Fischer-Kowalski. 2009. "Growth in Global Materials Use, GDP and Population During the 20th Century." Ecological Economics 68: 2696-2705. doi:10.1016/j.ecolecon.2009.05.007.

Launey, M. E., E. Munch, D. Alsem, E. Saiz, A. Tomsia, and R. Ritchie. 2010. "A Novel Biomimetic Approach to the Design of High-Performance Ceramic - Metal Composites." Journal of the Royal Society, Interface 7: 741-753. doi:10. 1098/rsif.2009.0331.

Lawless, A. 2005. "A Wake Up Call to Address the Capacity Crisis in SA Civil Engineering." Civil Engineering/Siviele Ingenieurswese 13: 40-43.

Lee, H., S. Dellatore, W. Miller, and P. Messersmith. 2007. "Mussel-Inspired Surface Chemistry for Multifunctional Coatings." Science 318: 426-430. doi:10.1126/science. 1147241

Lee, H., B. Lee, and P. Messersmith. 2007. "A Reversible Wet/ Dry Adhesive Inspired by Mussels and Geckos." Nature 448: 338-341. doi:10.1038/nature05968.

Lepora, N., P. Verschure, and T. Prescott. 2013. "The State of the Art in Biomimetics." Bioinspiration and Biomimetics 8: 013001. doi:10.1088/1748-3182/8/1/013001.

Liu, K., and L. Jiang. 2012. "Bio-Inspired Self-Cleaning Surfaces." Annual Review of Materials Research 42: 231-263. doi:10.1146/annurev-matsci-070511-155046.

Li, X., W. C. Chang, Y. Chao, R. Wang, and M. Chang. 2004. "Nanoscale Structural and Mechanical Characterization of a Natural of a Natural Nanocomposite Material: The Shell of Red Abalone." Nano Letters 4: 613-617. doi:10.1021/ nl049962k.

Martin, J., E. Roy, S. Diemont, and B. Fergunson. 2010. "Traditional Ecological Knowledge (TEK): Ideas, Inspiration, and Designs for Ecological Engineering." Ecological Engineering 36: 839-849. doi:10.1016/j.ecoleng.2010.04. 001.

Mayer, G. 2006. "New Classes of Tough Composite Materials Lessons from Natural Rigid Biological Systems." Materials Science Engineering C 26: 1261-1268. doi:10.1016/j.msec. 2005.08.031.

Meadows, D. H., D. L. Meadows, J. Randers, and W. Behrens. 1972. The Limits to Growth. Cambridge, MA: MIT Press.

Meadows, D. H., J. Randers, and D. L. Meadows. 1992. Beyond the Limits: Global Collapse or a Sustainable Future. Oxford: Earthscan.

Meyers, M., P. Y. Chen, A. Lin, and Y. Seki. 2008. "Biological Materials: Structure and Mechanical Properties." Progress in Materials Science 53: 1-206. doi:10.1016/j.pmatsci.2007. 05.002 .

Meyers, M., C. Limb, A. Li, B. Nizam, E. Tan, Y. Seki, and J. McKittrick. 2009. "The Role of Organic Intertile Layer in Abalone Nacre." Materials Science Engineering C 29: 2398-2410. doi:10.1016/j.msec.2009.07.005.

Mortensen, B. M., M. Haber, J. De Jong, L. Caslake, and D. Nelson. 2011. "Effects of Environmental Factors on Microbial Induced Calcium Carbonate Precipitation.” Journal of Applied Microbiology 111: 338-349. doi:10. 1111/j.1365-2672.2011.05065.x.
Pacheco-Torgal, F. 2013. "Eco-Efficient Construction and Building Materials Research Under the EU Framework Programme Horizon 2020." Construction and Building Materials, (Submitted for publication).

Pacheco-Torgal, F., and S. Jalali. 2011. Eco-Efficient Construction and Building Materials. London: Springer Verlag.

Pacheco-Torgal, F., and S. Jalali. 2012. "Earth Construction: Lessons from the Past for Future Eco-Efficient Construction." Construction and Building Materials 29: 512-519. doi:10.1016/j.conbuildmat.2011.10.054.

Pacheco-Torgal, F., and J. Labrincha. 2013. "The Future of Construction Materials Research and the Seventh UN Millennium Development Goal: A Few Insights." Construction and Building Materials 40: 729-737. doi:10.1016/j. conbuildmat.2012.11.007.

Pacheco-Torgal, F., S. Jalali, and F. Fucic. 2012. Toxicity of Building Materials. Cambridge: Woodhead Publishing Limited.

Pacheco-Torgal, F., J. Labrincha, V. John, Y. Ding, and V. Kar. 2013a. "Tackling Civil Engineering Course Decline with a Grand Cause: The Seventh Millennium Goal." In SEMC 2013 International Conference, Cape Town, South Africa.

Pacheco-Torgal, F., J. Labrincha, M. Diamanti, and C. P. Yu. 2013b. Biotechnologies and Biomimetics for Civil Engineering. Springer (Forthcoming).

Porter, D., and F. Vollrath. 2007. "Nanoscale Toughness of Spider Silk." Nanotoday 2 (3). doi:10.1016/S1748-0132(07) 70071-3.

Ramachandran, S., V. Ramakrishnan, and S. Bang. 2001. "Remediation of Concrete Using Micro-Organisms." ACI Materials Journal 98: 3-9.

Reddy, S., M. Seshagiri, P. Apama, and C. Sasikala. 2010. "Performance of Standard Grade Bacterial (Bacillus Subtilis) Concrete." Asian Journal of Civil Engineering (Building and Housing) 1: 43-55.

Samaha, M., H. Tafreshi, and M. Gad-el-Hak. 2012. "Superhydrophobic Surfaces: From the Lotus Leaf to the Submarine." Comptes Rendus Mecanique 340: 18-34. doi:10.1016/j.crme.2011.11.002.

Shimomura, M. 2010. "The New Trends in Next Generation Biomimetics Material Technology: Learning from Biodiversity." Quarterly Review 37: 53-75.

Singh, A. 2007. "Civil Engineering: Anachronism and Black Sheep." Journal of Professional Issues in Engineering Education and Practice 133: 18-30. doi:10.1061/(ASCE) 1052-3928(2007)133:1(18).

Stern, N. 2006. Stern Review on Economics of Climate Change. Cambridge: Cambridge University Press.

Tryggvason, G., and D. Apelian. 2006. "Re-Engineering Engineering Education for the Challenges of the 21st Century." JOM 58: 14-17.

Van Passen, L. 2011. "Bio-Mediated Ground Improvement: From Laboratory Experiment to Pilot Applications." Geotechnical Special Publication 211: 4099-4108. doi:10. 1061/41165(397)419.

Van Paassen, L. A., R. Ghose, J. Van der Linden, W. Van der Star, and M. Van Loosdrecht. 2010. "Quantifying Biomediated Ground Improvement by Ureolysis: Large-Scale Biogrout Experiment." Journal of Geotechnical and Geoenvironmental Engineering 136: 1721-1728. doi:10. 1061/(ASCE)GT.1943-5606.0000382.

Van Tittelboom, K., N. De Belie, W. De Muynck, and W. Verstraete. 2010. "Use of Bacteria to Repair Cracks in Concrete." Cement and Concrete Research 40: 157-166. doi:10.1016/j.cemconres.2009.08.025. 
Van Wijngaarden, W. K., F. Vermolen, G. Van Meurs, and C. Vuik. 2012. "A Mathematical Model and Analytical Solution for the Fixation of Bacteria in Biogrout." Transport in Porous Media 92: 847-866. doi:10.1007/s11242-0119937-0.

Wang, J., N. De Belie, and W. Verstraete. 2012. "Diatomaceous Earth as a Protective Vehicle for Bacteria Applied for SelfHealing Concrete." Journal of Industrial Microbiology and Biotechnology 39: 567-577. doi:10.1007/s10295-011-1037-1.

Wang, J., K. Van Tittelboom, N. De Belie, and W. Verstraete. 2012. "Use of Silica Gel or Polyurethane Immobilized Bacteria for Self-Healing Concrete." Construction and Building Materials 26: 532-540. doi:10.1016/j.conbuildmat.2011.06.054.

Weil, M. H., J. De Jong, B. Martinez, and B. Mortensen. 2012. "Seismic and Resistivity Measurements for Real-Time Monitoring of Microbially Induced Calcite Precipitation in Sand." Geotechnical Testing Journal 35 (2).
Wiktor, V., and H. Jonkers. 2011. "Quantification of CrackHealing in Novel Bacteria-Based Self-Healing Concrete." Cement and Concrete Composites 33: 763-770. doi:10. 1016/j.cemconcomp.2011.03.012.

Yu, F., S. Chen, H. Li, L. Yang, and Y. Yin. 2012. "Application of Self Assembled 6-Aminohexanol Layers for Corrosion Protection of 304 Stainless Steel Surface." Thin Solid Films 520: 4990-4995. doi:10.1016/j.tsf.2012.03.006.

Yurtseven, H. 2002. "How Does the Image of Engineering Affect Student Recruitment and Retention? A Perspective from the USA.” Global Journal of Engineering Education 6: 17-23.

Zheng, W., H. Shih, K. Lozano, and Y. L. Mo. 2011. "Impact of Nanotechnology on Future Civil Engineering Practice and its Reflection in Current Civil Engineering Education." Journal of Professional Issues in Engineering Education and Practice 137: 162-173. doi:10.1061/(ASCE)EI.1943-5541. 0000034. 